\title{
Photosynthetic and antioxidant performance are differentially affected by short-term nitrogen supply in highbush blueberry cultivars
}

\author{
Erwin Yañez-Mansilla', Paula Cartes ${ }^{2,3}$, Marjorie Reyes-Díaz ${ }^{2,3}$, Alejandra \\ Ribera-Fonseca ${ }^{3}$, and Miren Alberdi ${ }^{2,3}$ \\ ${ }^{1}$ Programa de Doctorado en Ciencias de Recursos Naturales, ${ }^{2}$ Departamento de Ciencias Químicas y \\ Recursos Naturales, Facultad de Ingeniería y Ciencias, ${ }^{3} \mathrm{Center}$ of Plant-Soil Interaction and Natural \\ Resources Biotechnology, Scientific and Technological Bioresource Nucleus (BIOREN), Universidad de La \\ Frontera, Avenida Francisco Salazar 01145, Temuco, Chile.
}

\begin{abstract}
E. Yañez-Mansilla, P. Cartes, M. Reyes-Díaz, A. Ribera-Fonseca, and M. Alberdi. 2014. Photosynthetic and antioxidant performance are differentially affected by short-term nitrogen supply in highbush blueberry cultivars. Cien. Inv. Agr. 41(1): 61-70. Nitrogen $(\mathrm{N})$ is an essential nutrient for photosynthesis and may influence phenolic compound synthesis in higher plants. The effect of different amounts of $\mathrm{N}(0$ to $38 \mathrm{mM})$ provided on a short-term (4 d) basis on the photosynthetic and antioxidant performance of highbush blueberry cultivars (Legacy and Bluegold) grown in a nutrient solution was studied. In both cultivars, the $\mathrm{N}$ concentration of leaves slightly increased in response to the $\mathrm{N}$ supply, with Bluegold frequently showing higher $\mathrm{N}$ concentrations than Legacy. Photosynthesis was reduced in Bluegold at the highest $\mathrm{N}$ dose, whereas in Legacy, a decrease of $\mathrm{CO}_{2}$ assimilation occurred under $\mathrm{N}$ starvation. This decrease in photosynthesis was accompanied by enhanced lipid peroxidation but only in Bluegold. In both cultivars superoxide dismutase (SOD) was activated with an increasing $\mathrm{N}$ supply. Legacy also showed increased SOD activity to counteract oxidative stress at higher $\mathrm{N}$ levels. Radical scavenging activity was not affected by the $\mathrm{N}$ supply. However, the total phenols and anthocyanins steadily declined in the leaves of Legacy, and flavonoids were significantly increased in the roots of both cultivars with increasing $\mathrm{N}$ treatments. Thus, our findings indicate that blueberry cultivars exhibit differential sensitivity to short-term N stress, and SOD appears to be more involved than phenolic compounds in the amelioration of $\mathrm{N}$-induced oxidative stress. Further studies are required to confirm the sensitivity to either $\mathrm{N}$ starvation in Legacy or $\mathrm{N}$ excess in Bluegold under long-term conditions.
\end{abstract}

Key words: Nitrogen, oxidative damage, phenolic compounds, superoxide dismutase, Vaccinium corymbosum.

\section{Introduction}

Nitrogen $(\mathrm{N})$ is well recognized as an essential element for plant growth and also regulates the

Received November 6, 2013. Accepted January 29, 2014. Corresponding author: miren.alberdi@ufrontera.cl synthesis of secondary metabolites, such as phenolic compounds (Ruan et al., 2010). Dissimilar responses to $\mathrm{N}$ supply have been observed to enhance, diminish or not influence phenolic compound accumulation in plants (Fritz et al., 2006; Mogren et al., 2006). 
It has been hypothesized that high $\mathrm{N}$ levels in plant tissues contribute to the formation of more amino acids and proteins for growth in relation to defense compounds (Bryant et al., 1983), such as secondary metabolites. Phenolics, rather than amino acid compounds, might be increased under $\mathrm{N}$ starvation. In fact, the accumulation of phenolics was increased by $\mathrm{N}$ depletion in a short-term study of Arabidopsis (Olsen et al., 2008). Moreover, the chlorogenic acid concentration was enhanced by two-fold in non-N treated chamomile plants compared with those supplied with $\mathrm{N}$ nutrition (Kováčik et al., 2007).

Conversely, the lack of $\mathrm{N}$ might trigger reactive oxygen species (ROS) accumulation and concomitant oxidative damage due to alterations in photosynthetic functionality (Huang et al., 2004; Pompelli et al., 2010). Nevertheless, the activity of antioxidant enzymes, superoxide dismutase (SOD) (Logan et al., 1999), and phenolic compounds, such as anthocyanins (Diaz et al., 2006), might counteract oxidative stress under $\mathrm{N}$ starvation.

Since 1985, the highbush blueberry (Vaccinium corymbosum L.) has become an important crop cultivated in Chile (Lyrene and Muñoz, 1997; Ribera et al., 2010). Nonetheless, information concerning the physiology of this crop beyond its beneficial effects is lacking. Moreover, there is scarce information about the $\mathrm{N}$ requirements of this crop, and to our knowledge, there are only a few reports demonstrating that blueberry can be sensitive to $\mathrm{N}$ excess, decreasing plant growth (Bañados et al., 2012). There is also a lack of research showing the relationship between $\mathrm{N}$ nutrition and antioxidant behavior for blueberry. The objective of this work was to study the effect of different short-term $\mathrm{N}$ concentrations on the photosynthetic and antioxidant performance of highbush blueberry cultivars grown in a nutrient solution.

\section{Materials and methods}

\section{Plant material and growth conditions}

Two-year-old highbush blueberry plants of two cultivars (Legacy and Bluegold) were grown in a nutrient solution for $4 \mathrm{~d}$ under greenhouse conditions, with a temperature of $25 / 20^{\circ} \mathrm{C}$ (day/night), photoperiod 16/8 h (light/dark) and 70\% relative humidity. Plants were conditioned in plastic boxes filled with $10 \mathrm{~L}$ of a modified Hoagland solution for $72 \mathrm{~h}$ (Hoagland and Arnon, 1950). Then, plants were transferred to containers with Hoagland solution without $\mathrm{N}$ for $72 \mathrm{~h}$. Thereafter, plants were subjected to different $\mathrm{NH}_{4} \mathrm{NO}_{3}$ concentrations in hydroponic solutions $(0,9,18,28$ or $38 \mathrm{mM} \mathrm{N})$ for a short period (4 d). Hydroponic solutions were continuously aerated, and the $\mathrm{pH}$ of the solutions was adjusted daily to 4.8 using $0.1 \mathrm{M} \mathrm{HCl}$. At the end of the experiment, in vivo $\mathrm{CO}_{2}$ assimilation measurements were determined. Completely expanded leaves from the second node and roots were also collected and stored at -20 or $-80^{\circ} \mathrm{C}$ for biochemical analyses; subsamples were dried for $\mathrm{N}$ concentration analyses.

\section{Measurements of $\mathrm{CO}_{2}$ assimilation}

Assimilation of $\mathrm{CO}_{2}$ was measured at the end of experiment between 9 and 10 a.m. in intact leaves belonging to the second node using a portable photosynthesis system (LI-6400, LI-COR Bioscience, Inc., Lincoln, Nebraska, US \& Canada) as described by Reyes-Díaz et al. (2011).

\section{Plant nitrogen concentration}

The nitrogen concentration in leaves and roots was determined using the Kjeldahl method (Sadzawka et al., 2004). The results were expressed as nitrogen concentration $\left(\mathrm{g} \mathrm{kg}^{-1} \mathrm{DW}\right)$. 
Lipid peroxidation and radical scavenging activity (RSA)

Thiobarbituric acid reactive substances (TBARS), as an index of oxidative stress, were measured in leaves and roots using a spectrophotometer according to the modified method of $\mathrm{Du}$ and Bramlage (1992) and the results were expressed as nmol of malondialdehyde (MDA) per $\mathrm{g}^{-1}$ of fresh weight. For the radical scavenging activity (RSA), the free radical 2.1-diphenyl-1-picrylhydrazyl (DPPH) scavenging method was used for leaves and roots at $515 \mathrm{~nm}$, using 6-hydroxy-2,5,7,8tetramethylchroman-2-carboxylic acid (Trolox) as a standard (Chinnici et al., 2004).

\section{Quantification of phenolic compounds}

Total phenols were determined at $765 \mathrm{~nm}$ by the Folin-Ciocalteu method, using chlorogenic acid as the standard (Slinkard and Singleton, 1977). Chlorogenic acid is the most abundant cinnamic derivative in highbush blueberry (Gao and Mazza, 1994). Thus, it is the better phenolic to be used as standard for total phenolic compounds determination. Total flavonoids were analyzed by the aluminum chloride colorimetric assay, using rutin as the standard (Cheng and Breen, 1991). Total anthocyanins were measured using a spectrophotometer by the $\mathrm{pH}$ differential method according Cheng and Breen (1991).

\section{Superoxide dismutase activity (SOD)}

The activity of SOD (EC. 1.15.1.1) was analyzed in leaves and roots by measuring the photochemical inhibition of nitroblue tetrazolium (NBT) at $560 \mathrm{~nm}$ (Giannopolitis and Ries, 1977). One SOD unit was defined as the amount of enzyme corresponding to $50 \%$ inhibition of NBT reduction (Donahue et al., 1997). The enzyme activity was expressed on a protein basis, and the protein concentration was measured at $595 \mathrm{~nm}$ using the Bradford (1976) method.

\section{Data analyses}

Chemical and biochemical data were analyzed by two-way ANOVA following normality and homoscedasticity tests. Tukey's test was used to evaluate differences between the means $(\mathrm{P} \leq 0.05)$. In addition, Pearson correlations were used to assess the relationships between the two response variables. Analyses were performed with Sigma Stat software v. 2.0 (SPSS, Chicago, IL, USA).

\section{Results}

For both cultivars, differential responses were observed in $\mathrm{CO}_{2}$ assimilation as a result of different $\mathrm{N}$ doses (Figure 1). When no $\mathrm{N}$ was applied, a decrease of approximately $28 \%$ in photosynthesis was found in the Legacy variety. There was no variation in the response of the plants grown with an increasing $\mathrm{N}$ supply. Conversely, in Bluegold, there was no effect of the $\mathrm{N}$ supply on $\mathrm{CO}_{2}$ assimilation, except at the highest $\mathrm{N}$ dose, which decreased photosynthesis by approximately $60 \%$ $(\mathrm{P} \leq 0.05)$.

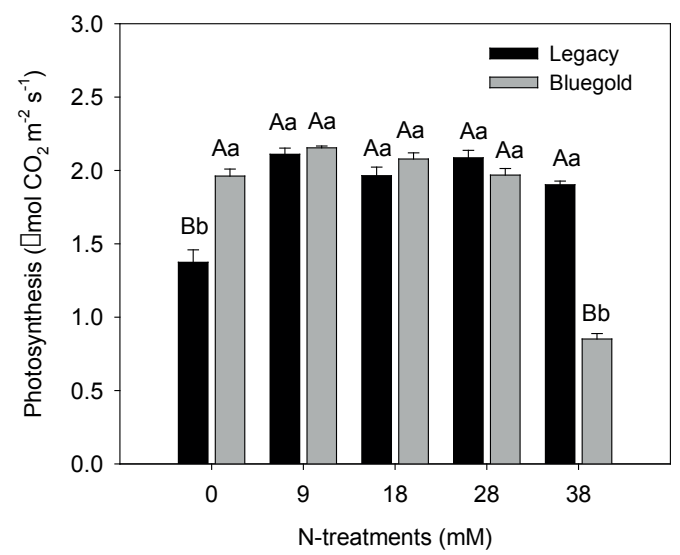

Figure 1. Photosynthetic rates of two highbush blueberry cultivars grown under different short-term $\mathrm{N}$ treatments. The values represent the average of three replicates \pm SE. Different lowercase letters indicate statistically significant differences among $\mathrm{N}$ treatments for the same cultivar. Different uppercase letters indicate statistically significant differences between cultivars for the same $\mathrm{N}$ treatment $(\mathrm{P} \leq 0.05)$. 
No statistically significant interaction between cultivars and $\mathrm{N}$ treatments for the $\mathrm{N}$ concentration was found either for leaves $(\mathrm{P}=0.055)$ or for roots $(\mathrm{P}=0.327)$. In Bluegold, a significant increase in the leaf $\mathrm{N}$ concentration was observed in the 9 $\mathrm{mM} \mathrm{N}$ treatment compared with the $0 \mathrm{~N}$ treatment, whereas in Legacy, the leaf $\mathrm{N}$ concentration was stable in treatments of 0 to $28 \mathrm{mM} \mathrm{N}$ and increased only at $38 \mathrm{mM} \mathrm{N}$ (Table 1). Thus, the $\mathrm{N}$ concentration in leaves was frequently higher $(\mathrm{P} \leq 0.05)$ in Bluegold than in Legacy. Both cultivars had similar root $\mathrm{N}$ concentrations across all $\mathrm{N}$ treatments (Table 1).

Nitrogen applications did not significantly influence lipid peroxidation in leaves and roots of Bluegold at $\mathrm{N}$ application levels up to $28 \mathrm{mM}$, but lipid peroxidation increased by approximately $10 \%$ (leaves) and 34\% (roots) in the highest $\mathrm{N}$ treatment (Table 1). In Legacy leaves, major oxidative damage was found from 0 to $18 \mathrm{mM}$ and decreased at higher $\mathrm{N}$ concentrations, whereas in roots, it did not vary significantly due to the $\mathrm{N}$ treatments (Table 1).
A statistically significant interaction between the cultivars and $\mathrm{N}$ treatments for SOD activity was found for leaves $(\mathrm{P} \leq 0.001)$ and roots $(\mathrm{P}=0.008)$. The activity of SOD was higher in Legacy than Bluegold leaves at each $\mathrm{N}$ treatment $(\mathrm{P} \leq 0.05)$, except at the highest level of $\mathrm{N}$ applied (Table 1). In addition, SOD was activated both under $\mathrm{N}$ starvation and $\mathrm{N}$ addition levels above 18 $\mathrm{mM}$ compared with $9 \mathrm{mM}$ in Legacy leaves. In Bluegold leaves, SOD activity rose progressively as the $\mathrm{N}$ supply increased and was approximately $95 \%$ higher at $38 \mathrm{mM} \mathrm{N}$ in comparison with plants grown without N. In Legacy and Bluegold roots, a significant increase of SOD activity was detected in $\mathrm{N}$ treatments up to $28 \mathrm{mM} \mathrm{N}$.

In terms of RSA, leaves showed a higher antioxidant activity than roots in both cultivars, and in general, no significant differences were found due to $\mathrm{N}$ treatments or between cultivars (Table 1).

In leaves, there was significant interaction between $\mathrm{N}$ treatments and cultivars for total phenols $(P \leq 0.001)$, flavonoids $(P \leq 0.001)$ and anthocya-

Table 1. Chemical and biochemical properties of leaves and roots of highbush blueberry cultivars grown under different short-term $\mathrm{N}$ treatments.

\begin{tabular}{|c|c|c|c|c|c|c|c|c|c|}
\hline \multirow{2}{*}{$\begin{array}{l}\mathrm{N} \\
\text { treatments } \\
(\mathrm{mM})\end{array}$} & \multirow[b]{2}{*}{ Cultivars } & \multicolumn{2}{|c|}{$\begin{array}{l}\text { N concentration } \\
\left(\mathrm{g} \mathrm{kg}^{-1} \mathrm{DW}\right)\end{array}$} & \multicolumn{2}{|c|}{$\begin{array}{l}\text { Lipid peroxidation } \\
\left(\mathrm{nmol} \mathrm{MDA} \mathrm{g}{ }^{-1} \mathrm{FW}\right)\end{array}$} & \multicolumn{2}{|c|}{$\begin{array}{l}\text { SOD activity } \\
\text { (U mg-1 protein) }\end{array}$} & \multicolumn{2}{|c|}{$\begin{array}{l}\text { Radical scavenging } \\
\text { activity } \\
\left(\mathrm{mg} \mathrm{TE} \mathrm{g}^{-1} \mathrm{FW}\right)\end{array}$} \\
\hline & & Leaves & Roots & Leaves & Roots & Leaves & Roots & Leaves & Roots \\
\hline 0 & Legacy & $14.2 \pm 0.9 \mathrm{Ab}$ & $11.3 \pm 0.7 \mathrm{Aa}$ & $129 \pm 7 \mathrm{Aa}$ & $56.5 \pm 1.2 \mathrm{Aa}$ & $229 \pm 6 \mathrm{Ab}$ & $69 \pm 12 \mathrm{Ac}$ & $11.1 \pm 1.4 \mathrm{Aa}$ & $2.8 \pm 0.3 \mathrm{Aa}$ \\
\hline 9 & & $13.1 \pm 0.1 \mathrm{Bb}$ & $13.1 \pm 0.6 \mathrm{Aa}$ & $119 \pm 3 \mathrm{Aa}$ & $58.2 \pm 1.1 \mathrm{Aa}$ & $204 \pm 7 \mathrm{Ac}$ & $93 \pm 2 \mathrm{Abc}$ & $10.6 \pm 1.3 \mathrm{Aa}$ & $3.0 \pm 0.3 \mathrm{Aa}$ \\
\hline 18 & & $13.6 \pm 0.5 \mathrm{Bb}$ & $13.1 \pm 1.0 \mathrm{Aa}$ & $124 \pm 12 \mathrm{Aa}$ & $56.2 \pm 3.5 \mathrm{Aa}$ & $222 \pm 18 \mathrm{Abc}$ & $140 \pm 13 \mathrm{Aa}$ & $9.7 \pm 1.3 \mathrm{Aa}$ & $2.4 \pm 0.3 \mathrm{Aa}$ \\
\hline 28 & & $14.1 \pm 0.7 \mathrm{Bb}$ & $12.8 \pm 0.7 \mathrm{Aa}$ & $96 \pm 1 \mathrm{Bb}$ & $53.5 \pm 2.2 \mathrm{Aa}$ & $251 \pm 9 \mathrm{Aa}$ & $164 \pm 10 \mathrm{Aa}$ & $8.9 \pm 0.6 \mathrm{Aa}$ & $2.6 \pm 0.2 \mathrm{Aa}$ \\
\hline 38 & & $16.2 \pm 0.8 \mathrm{Aa}$ & $12.6 \pm 0.02 \mathrm{Aa}$ & $91 \pm 4 \mathrm{Bb}$ & $53.2 \pm 5.0 \mathrm{Aa}$ & $251 \pm 2 \mathrm{Aa}$ & $113 \pm 2 \mathrm{Ab}$ & $10.6 \pm 0.7 \mathrm{Aa}$ & $2.5 \pm 0.5 \mathrm{Aa}$ \\
\hline 0 & Bluegold & $14.9 \pm 0.6 \mathrm{Ab}$ & $12.4 \pm 0.1 \mathrm{Aa}$ & $119 \pm 9 \mathrm{Ab}$ & $45.1 \pm 6.2 \mathrm{Bb}$ & $124 \pm 6 \mathrm{Bd}$ & $71 \pm 6 \mathrm{Ab}$ & $9.3 \pm 0.1 \mathrm{Aa}$ & $2.3 \pm 0.5 \mathrm{Aa}$ \\
\hline 9 & & $17.3 \pm 0.3 \mathrm{Aa}$ & $12.6 \pm 0.4 \mathrm{Aa}$ & $110 \pm 10 \mathrm{Ab}$ & $49.5 \pm 3.3 \mathrm{Bb}$ & $120 \pm 10 \mathrm{Bd}$ & $94 \pm 11 \mathrm{Ab}$ & $9.6 \pm 1.3 \mathrm{Aa}$ & $2.6 \pm 0.1 \mathrm{Aa}$ \\
\hline 18 & & $17.2 \pm 1.3 \mathrm{Aa}$ & $11.9 \pm 0.7 \mathrm{Aa}$ & $119 \pm 1 \mathrm{Ab}$ & $48.2 \pm 2.5 \mathrm{Ab}$ & $166 \pm 11 \mathrm{Bc}$ & $75 \pm 1 \mathrm{Bb}$ & $7.3 \pm 0.1 \mathrm{Bb}$ & $2.8 \pm 0.3 \mathrm{Aa}$ \\
\hline 28 & & $18.4 \pm 0.5 \mathrm{Aa}$ & $12.4 \pm 0.2 \mathrm{Aa}$ & $114 \pm 1 \mathrm{Ab}$ & $50.8 \pm 1.7 \mathrm{Ab}$ & $192 \pm 11 \mathrm{Bb}$ & $123 \pm 7 \mathrm{Ba}$ & $9.8 \pm 0.2 \mathrm{Aa}$ & $2.7 \pm 0.1 \mathrm{Aa}$ \\
\hline 38 & & $17.9 \pm 0.4 \mathrm{Aa}$ & $13.4 \pm 0.3 \mathrm{Aa}$ & $130 \pm 2 \mathrm{Aa}$ & $60.5 \pm 0.9 \mathrm{Aa}$ & $241 \pm 15 \mathrm{Aa}$ & $82 \pm 5 \mathrm{Bb}$ & $9.8 \pm 0.2 \mathrm{Aa}$ & $2.9 \pm 0.1 \mathrm{Aa}$ \\
\hline
\end{tabular}

The values represent the average of three replicates \pm SE.

Different lowercase letters indicate statistically significant differences among $\mathrm{N}$ treatments for the same cultivar.

Different uppercase letters indicate statistically significant differences between cultivars for the same $\mathrm{N}$ treatment $(\mathrm{P} \leq 0.05)$. 
nins ( $\mathrm{P}=0.006)$, whereas for roots, a statistically significant interaction was only found for total phenols $(\mathrm{P}=0.024)$. In both cultivars, more phenols were accumulated in leaves than in roots (Figure 2a, b). The total phenols in leaves did not statistically vary in Legacy up to $18 \mathrm{mM} \mathrm{N}$ but decreased at 28 and $38 \mathrm{mM} \mathrm{N}$, resulting in an approximately 3 -fold difference between the 0 and $38 \mathrm{mM} \mathrm{N}$ treatments. In contrast, Bluegold leaves showed no difference in phenolic concentrations. In general, Legacy accumulated more phenols than Bluegold in roots (Figure 2b). No difference in the concentration of phenols was observed in Bluegold roots under an increasing $\mathrm{N}$ supply, but a decrease of approximately $23 \%$ occurred at 28 and $38 \mathrm{mM} \mathrm{N}$ compared with 0 $\mathrm{mM} \mathrm{N}$ in Legacy roots.
Even though leaf flavonoids in Bluegold were not significantly affected by the $\mathrm{N}$ treatments, they were reduced by nearly $20 \%$ in Legacy at the highest $\mathrm{N}$ application (Figure 2c). In the roots of both cultivars, the total flavonoids increased due to the $\mathrm{N}$ supply. In fact, $\mathrm{N}$-treated plants exhibited 2-fold higher flavonoid concentrations than $\mathrm{N}$-starved plants (Figure 2d). Under $\mathrm{N}$ addition, Legacy roots had an $18 \%$ greater flavonoid concentration than Bluegold roots for all $\mathrm{N}$ treatments (Figure 2d). Furthermore, the anthocyanin concentration in Legacy leaves was highest at $0 \mathrm{~N}$ and decreased by $29 \%$ under $\mathrm{N}$ supply. In Bluegold leaves, anthocyanin accumulation was not affected up to $28 \mathrm{mM} \mathrm{N}$ but was reduced by approximately $42 \%$ at the highest $\mathrm{N}$ dose (Figure 3).

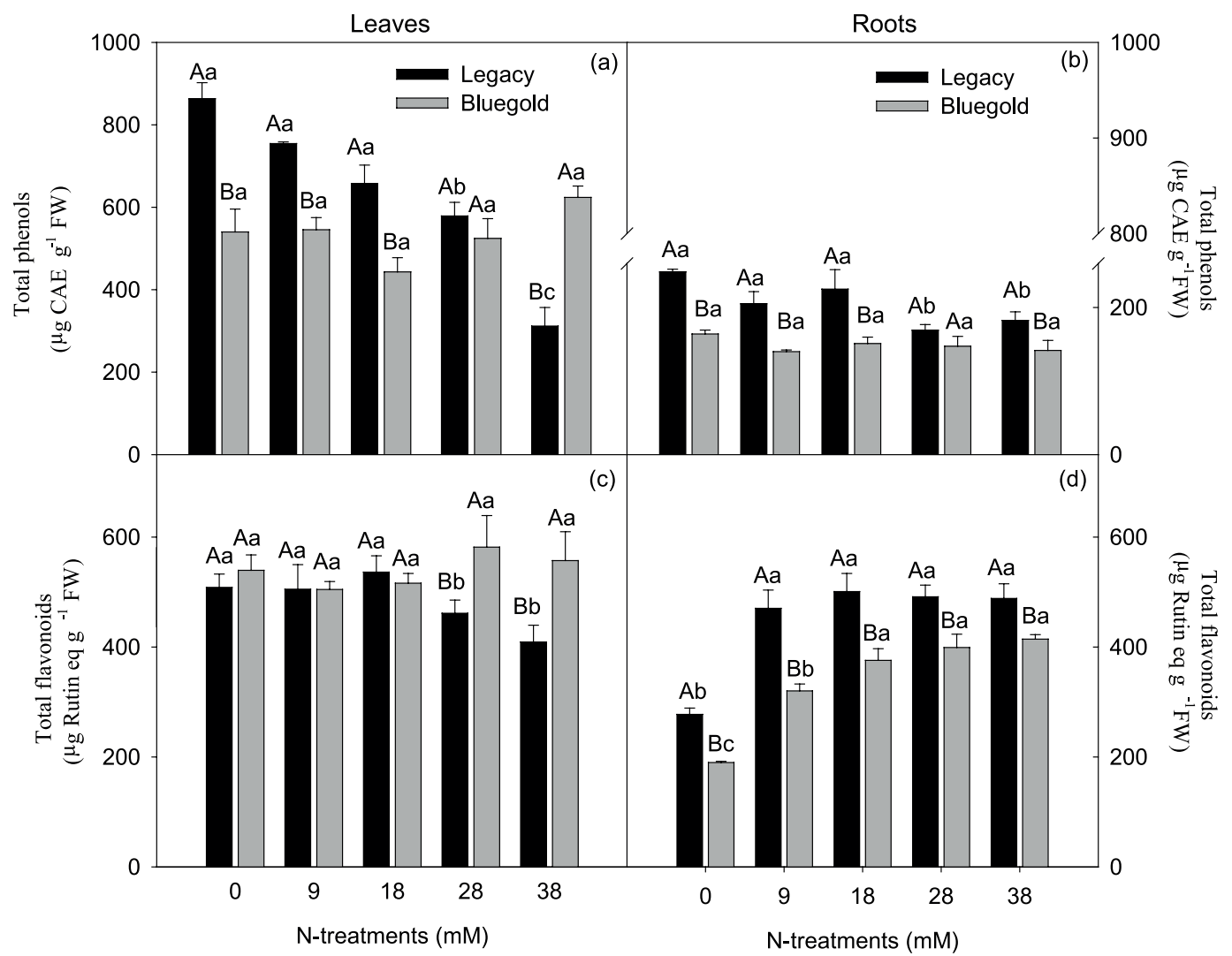

Figure 2. Total phenols and flavonoids in leaves and roots of highbush blueberry cultivars grown under different short-term $\mathrm{N}$ treatments. The values represent the average of three replicates $\pm \mathrm{SE}$. Different lowercase letters indicate statistically significant differences among $\mathrm{N}$ treatments for the same cultivar. Different uppercase letters indicate statistically significant differences between cultivars for the same $\mathrm{N}$ treatment $(\mathrm{P} \leq 0.05)$. 


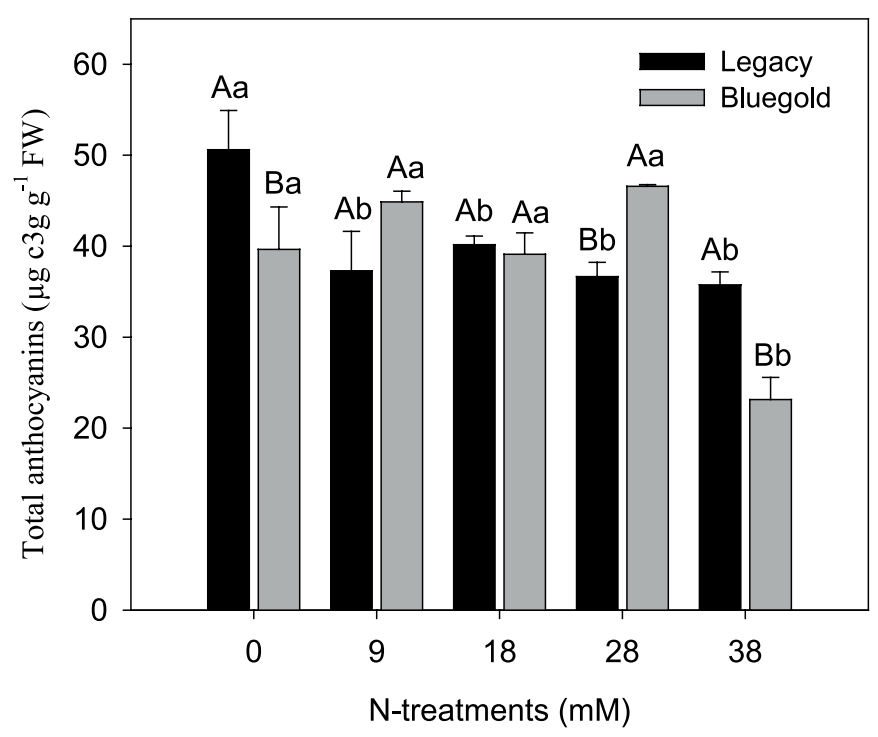

Figure 3. Anthocyanins in leaves of highbush blueberry cultivars grown under different short-term $\mathrm{N}$ treatments. The values represent the average of three replicates \pm SE. Different lowercase letters indicate statistically significant differences among $\mathrm{N}$ treatments for the same cultivar. Different uppercase letters indicate statistically significant differences between cultivars for the same $\mathrm{N}$ treatment $(\mathrm{P} \leq 0.05)$.

\section{Discussion}

Nitrogen $(\mathrm{N})$ is an essential nutrient for photosynthesis, plant growth and development. It is also involved in the regulation of secondary metabolite synthesis, mainly in phenolic compounds (Ruan et al., 2010). In this study, the effects of different short-term $\mathrm{N}$ treatments on the chemical, physiological and biochemical characteristics of highbush blueberry were evaluated. It is widely reported that leaves and fruits of blueberry exhibit a particularly high content of phenolic compounds (Ribera et al., 2010), which could be affected by the short-term $\mathrm{N}$ supply as previously found for other plants, such as Arabidopsis and chamomile (Kováčik et al., 2007; Olsen et al., 2008).

Our results demonstrated that $\mathrm{N}$ treatments influenced the $\mathrm{N}$ concentration in leaves of both cultivars (Table 1). Although Bluegold typically had higher leaf $\mathrm{N}$ concentrations than Legacy, all of the $\mathrm{N}$ contents reported here are within the normal range described by Bañados et al. (2012) for blueberry.
In contrast, our findings indicated that photosynthesis was reduced in Legacy under $\mathrm{N}$ starvation without any increase of lipid peroxidation (Figure 1, Table 1). Possible explanations for a decrease of $\mathrm{CO}_{2}$ assimilation under the $0 \mathrm{~N}$ treatment in leaves might include: i) a reduced stomata aperture, lowering carbon fixation in the mesophyll tissue (Wong, 1979); ii) a decline of the stomatal conductance (Radin and Ackerson, 1981); or iii) a decrease in proteins, such as RUBISCO (Buchanan et al., 2000). Moreover, studies have demonstrated that a $\mathrm{N}$ deficiency can decrease the content of photosynthetic pigments, thereby reducing the photosynthetic performance of plants (Huang et al., 2004).

Conversely, photosynthesis was significantly reduced in Bluegold at the highest $\mathrm{N}$ level (Figure 1), which was accompanied by an increase in oxidative damage (Table 1). Excess nitrogen is frequently associated with ammonium $\left(\mathrm{NH}_{4}^{+}\right)$ toxicity in vascular plants (Hachiya et al., 2012). The negative impacts of a high $\mathrm{NH}_{4}^{+}$accumulation in plant tissues might be a consequence of 
$\mathrm{H}^{+}$consumption by the conversion of ammonia $\left(\mathrm{NH}_{3}\right)$ to $\mathrm{NH}_{4}^{+}$provoking the uncoupling of the $\mathrm{H}^{+}$ gradient in biological membranes (Bloom et al., 1992), which might drive the decline in photosynthesis. In addition, Pompelli et al. (2010) indicated that high $\mathrm{N}$ addition levels could increase ROS production in cell membranes due to failure in photosynthesis. It has been well recognized that $\mathrm{N}$ stress (excess or deficiency) can trigger ROS production, affecting cell membranes as well as the integrity of chloroplasts and photosynthetic machinery (Buchanan et al., 2000).

Non-enzymatic and enzymatic antioxidant defenses could help to protect the photosynthetic apparatus against $\mathrm{N}$-induced oxidative stress. The results regarding the effect of $\mathrm{N}$ nutrition on phenolic content are controversial. Some reports have indicated that the $\mathrm{N}$ supply did not influence the phenolic accumulation in leaves and roots of onion (Mogren et al., 2006), whereas Logan et al. (1999) detected a low content of phenolics in plants grown under $\mathrm{N}$ deprivation. In contrast, high $\mathrm{N}$ levels in growth media have been associated with a reduction of both the content of phenolic compounds and the antioxidant capacity in vascular plants ((Royer et al., 2013). In our study, leaves of Legacy showed a decrease in phenols (Figure 2a), including flavonoids (Figure 2c) and anthocyanins (Figure 3 ), as a consequence of increasing $\mathrm{N}$ additions. There was a significant inverse correlation between the total phenols and the $\mathrm{N}$ concentration in Legacy leaves $(\mathrm{r}=-0.609, \mathrm{P} \leq 0.05)$. These findings agree with the hypothesis of Bryant et al. (1983) that plants growing under high $\mathrm{N}$ levels allocate $\mathrm{N}$ resources to the formation of new tissues and not for the synthesis of phenolics. In addition, we found that the root flavonoid content increased in response to the $\mathrm{N}$ supply (Figure 2d), mainly in Legacy, and we observed that the leaf antioxidant activity was maintained under all $\mathrm{N}$ treatments in both cultivars (Table 1). Likewise, SOD activity was high under $\mathrm{N}$ deprivation and at high $\mathrm{N}$ doses in Legacy leaves, counteracting oxidative stress at the greater $\mathrm{N}$ levels (Table 1). In contrast, the enzyme activity steadily increased in Bluegold leaves with the increasing $\mathrm{N}$ supply. In this cultivar, such an activation appears to be responsible for the maintenance of lipid peroxidation at basal levels (up to $28 \mathrm{mM} \mathrm{N}$ ) but not under the highest $\mathrm{N}$ treatments (Table 1). This behavior denotes a greater sensitivity of Bluegold to $\mathrm{N}$ excess compared with Legacy.

Thus, although both cultivars exhibited similar patterns for short-term $\mathrm{N}$ accumulation, we observed dissimilar plant performance between them with $\mathrm{N}$ starvation or $\mathrm{N}$ excess. Based on our results regarding photosynthesis and oxidative stress, further studies are required to confirm the long-term sensitivity of $\mathrm{N}$ starvation in Legacy and $\mathrm{N}$ excess in Bluegold.

We conclude that blueberry cultivars differ in sensitivity to short-term $\mathrm{N}$ starvation or $\mathrm{N}$ excess, as demonstrated by the dissimilar effects of an increased $\mathrm{N}$ supply on photosynthesis and antioxidant performance. In this regard, SOD activity appears to be more important than nonenzymatic antioxidant compounds for protection against oxidative stress induced by $\mathrm{N}$ excess. In conclusion, $\mathrm{N}$ excess can trigger a considerable decrease of leaf phenolic compounds (including anthocyanins) depending on the blueberry cultivar, which can reduce not only plant productivity but also its nutraceutical value as well as crop profitability.

\section{Acknowledgments}

Financial support was provided by the FONDECYT project 1110726. E. Yañez-Mansilla was supported by a PhD CONICYT Scholarship Chile and the Office of Research, Universidad de La Frontera. 


\section{Resumen}

E. Yañez-Mansilla, P. Cartes, M. Reyes-Díaz, A. Ribera-Fonseca y M. Alberdi. 2014. El desempeño fotosintético $y$ antioxidante son afectados diferencialmente por el suministro de nitrógeno en cultivares de arándano alto en el corto tiempo. Cien. Inv. Agr. 41(1): 61-70. El nitrógeno $(\mathrm{N})$ es un nutriente esencial para la fotosíntesis, el cual puede afectar la síntesis de compuestos fenólicos en plantas superiores. Se estudió el efecto de diferentes dosis de nitrógeno (0 a $38 \mathrm{mM}$ ) en el desempeño fotosintético y antioxidante en cultivares de arándano alto (Legacy y Bluegold) creciendo en solución nutritiva en tiempo corto (4 d). En ambos cultivares, la concentración de $\mathrm{N}$ de las hojas incrementó levemente en respuesta a la aplicación de $\mathrm{N}$, mostrando Bluegold frecuentemente mayores concentraciones de $\mathrm{N}$ que Legacy. La fotosíntesis disminuyó en Bluegold a la dosis más alta de N, mientras que en Legacy esta reducción ocurrió en condiciones de privación de N. Este descenso en la fotosíntesis fue acompañado por una elevada peroxidación lipídica en Bluegold. En ambos cultivares SOD fue activada a medida que incrementó el aporte de N. Legacy también mostró un incremento en la actividad SOD que contrarrestó el estrés oxidativo a las mayores adiciones de N. La actividad de remoción de radicales libres no fue afectada por la adición de N. Sin embargo, los contenidos de fenoles totales y antocianinas disminuyeron paulatinamente en hojas de Legacy, y el de flavonoides incrementó significativamente en raíces de ambos cultivares a medida que el suministro de $\mathrm{N}$ aumentó. Así, nuestros resultados indican que los cultivares de arándano alto exhiben diferente sensibilidad al estrés por $\mathrm{N}$ en el corto tiempo y que SOD parece estar más involucrada que los compuestos fenólicos en la atenuación del estrés oxidativo inducido por N. Futuros estudios se requieren para confirmar la sensibilidad ya sea a la privación de $\mathrm{N}$ en Legacy o al exceso de éste en Bluegold en tiempo largo.

Palabras clave: Compuestos fenólicos, daño oxidativo, nitrógeno, superóxido dismutasa, Vaccinium corymbosum.

\section{References}

Bañados, M.P., B.C. Strik, and D.B. Bryla. 2012. Response of highbush blueberry to nitrogen fertilizer during field establishment, I: accumulation and allocation of fertilizer nitrogen and biomass. HortScience 47:648-655.

Bloom, A.J., S.S. Sukrapanna, and R.L Warner. 1992. Root respiration associated with ammonium and nitrate absorption and assimilation by barley. Plant Physiol. 99:1294-1301.

Bradford, M.M. 1976. A rapid and sensitive method for the quantification of microgram quantities of protein utilizing the principle of protein-dye binding. Anal Biochem.72:248-254.

Bryant, J.P., F.S. Chapin, and D.R. Klein. 1983. Carbon/nutrient balance of boreal plants in relation to vertebrate herbivory. Oikos 40:357-368.
Buchanan, B.B., W. Gruissem, and R.L. Jones. 2000. Biochemistry and molecular biology of plants. Rockville, MD: American Society of Plant Physiologists. Rockville, Maryland, USA. p. 1367.

Diaz, C., V. Saliba-Colombani, O. Loudet, P. Belluomo, L. Moreau, F. Daniel-Vedele, J.F. MorotGaudry, and C. Masclaux-Daubresse. 2006. Leaf yellowing and anthocyanin accumulation are two genetically independent strategies in response to nitrogen limitation in Arabidopsis thaliana. Plant Cell Physiol. 47:74-83.

Chang, C.C., M.H. Yang, H.M. Wen, and J.C. Chern. 2002. Estimation of total flavonoid content in Propolis by two complementary colorimetric methods. J. Food Drug Anal. 10:178-182.

Cheng, G.W., and P.J. Breen. 1991. Activity of phenylalanine ammonia-lyase (PAL) and concentrations of anthocyanins and phenolics in devel- 
oping strawberry fruit. J. Amer. Soc. Hort Sci. 116:865-869.

Chinnici, F., A.A. Bendini, A. Gaiani, and C. Riponi. 2004. Radical scavenging activities of peels and pulps from cv. Golden delicious apples as related to their phenolic composition. J. Agr. Food Chem. 52:4684-4689.

Donahue, J.L., C.M. Okpodu, C.L. Cramer, E.A. Grabau, and R.G. Aslcher. 1997. Responses of antioxidant to paraquat in pea leaves, Relationships to resistance. Plant Physiol. 113:249-247.

Du, Z., and W.J. Bramlage. 1992. Modified thiobarbituric acid assay for measuring lipid peroxidation in sugar rich plant tissue extracts. J. Agr. Food Chem. 40:1566-1570.

Fritz, C., N. Palacios-Rojas, R. Feil, and M. Stitt. 2006. Regulation of secondary metabolism by the carbon-nitrogen status in tobacco: nitrate inhibits large sectors of phenylpropanoid metabolism. The Plant Journal 46:533-548.

Gao, L. and Mazza, G. 1994. Quantification and distribution of simple and acylated anthocyanins and other phenolics in blueberries. J. Food Sci. 59: 1057-1059.

Giannopolitis, C.N., and S.K. Ries. 1977. Superoxide dismutases-occurrence in higher plants. Plant Physiol. 59:309-314.

Hachiya, T., C.K. Watanabe, M. Fujimoto, T. Ishikawa, K. Takahara, M. Kawai-Yamada, H. Uchimiya, Y. Uesono, I. Terashima, and K. Noguchi. 2012. Nitrate addition alleviates ammonium toxicity without lessening ammonium accumulation, organic acid depletion and inorganic cation depletion in Arabidopsis thaliana shoots. Plant Cell Physiol. 53:577-91.

Hoagland, D.R., and D.I. Arnon. 1950. The water culture method for growing plants without soil. Berkeley, California. College of Agriculture, University of California. Circular 347:1-32.

Huang, Z.A., D.A. Jiang, Y. Yang, J.W. Sun, and S.H. Jin. 2004. Effects of nitrogen deficiency on gas exchange, chlorophyll fluorescence and antioxidant enzymes in leaves of rice plants. Photosynthetica 42:357-364.

Kováčik, J., B. Klejdus, M. Bačkor, and M. Repčák. 2007. Phenylalanine ammonia-lyase activity and phenolic compounds accumulation in nitrogendeficient Matricaria chamomilla leaf rosettes. Plant Sci. 172:393-399.

Logan, B., B. Demmig-Adams, T. Rosenstiel, and W. Adams. 1999. Effect of nitrogen limitation on foliar antioxidants in relationship to other metabolic characteristics. Planta 209:213-220.

Lyrene, P.M., and C. Muñoz. 1997. Blueberry Production in Chile. J. Small Fruit Vitic. 5:1-20.

Mogren, L.M., M.E. Olsson, and U.E. Gertsson. 2006. Quercetin content in field-cured onions (Allium cepa L.): effects of cultivar, lifting time, and nitrogen fertilizer level. J. Agr. Food Chem. 54:6185-6191.

Pompelli, M.F., S.C.V. Martins, W.C. Antunes, A.R.M. Chaves, and F.M. Damatta. 2010. Photosynthesis and photoprotection in coffee leaves is affected by nitrogen and light availabilities in winter conditions. J. Plant Physiol. 167:10521060.

Olsen, K.M., U.S. Lea, R. Slimestad, M. Verheul, and C. Lillo. 2008. Differential expression of four Arabidopsis PAL genes; PAL1 and PAL2 have functional specialization in abiotic environmental-triggered flavonoid synthesis. J. Plant Physiol. 165:1491-1499.

Radin, J.W., and R.C. Ackerson. 1981. Water relations of cotton plants under nitrogen deficiency. III. Stomatal conductance, photosynthesis and abscisic acid accumulation. Plant Physiol. 67:115-119.

Reyes-Díaz, M., C. Meriño-Gergichevich, E. Alarcón, M. Alberdi, and W.J. Horst. 2011. Calcium sulfate ameliorates the effect of aluminum toxicity differentially in genotypes of highbush blueberry (Vaccinium corymbosum L.). J. Soil. Sci. Plant Nutr. 11:59-78.

Ribera, A.E., M. Reyes-Diaz, M. Alberdi, G.E. Zuñiga, and M.L. Mora. 2010. Antioxidant compounds in skin and pulp of fruits change among genotypes and maturity stages in highbush blueberry (Vaccinium corymbosum L.) grown in Southern Chile. J.Soil Sci. Plant Nutr. 10:509536.

Royer, M., R. Larbat, J. Le Bot, S. Adamowicz, and C. Robin. 2013. Is the C:N ratio a reliable in- 
dicator of $\mathrm{C}$ allocation to primary and defencerelated metabolisms in tomato?. Phytochemistry. 88:25-33.

Ruan, J., R. Haerdter, and J. Gerendás. 2010. Impact of nitrogen supply on carbon/nitrogen allocation: a case study on amino acids and catechins in green tea Camellia sinensis (L.) O. Kuntze plants. Plant Biology 12:724-734.

Sadzawka, A., R. Grez, M.L. Mora, N. Saavedra, M.A. Carrasco, H. Flores, and C. Rojas. 2004. Métodos de análisis de tejidos vegetales. Comis- ión de Normalización y Acreditación, Sociedad Chilena de la Ciencia del Suelo. Editorial Salesianos Impresores. Santiago, Chile. 113 pp.

Slinkard, K., and V.A. Singleton. 1977. Total phenol analysis: automation and comparison with manual methods. Am. J. Enol. Viticul. 28:29-55.

Wong, S.C. 1979. Elevated atmospheric partial pressure of $\mathrm{CO}_{2}$ and plant growth. I Interaction of nitrogen nutrition and photosynthetic capacity in C3 and C4 plants. Oecologia 44:68-74. 